\title{
An error analysis of using auxiliary verb in Islamic mathematical complex questions made by mathematics department students
}

\author{
Haris Dibdyaningsih \\ haris@hikmahuniversity.ac.id \\ STKIP Al Hikmah Surabaya
}

Hendra Sudarso

hendrasudarso@stkippgri-bkl.ac.id

STKIP PGRI Bangkalan

\begin{abstract}
The purpose of this study is to describe students' error in applying auxiliary verb in writing Islamic Mathematical complex Questions. The participants were nine Mathematics department students of STKIP Al Hikmah who took English for writing course on the third semester. One of the purposes of this course is the students could compose a good Islamic Mathematical complex Questions using a proper grammar. To reach the purpose of this course, the students are equipped with compilation of English mathematical complex questions in Bahasa. For passing the course as the project they must create minimum 50 questions of Islamic Mathematics complex Questions based on the topic in VIII Grade of Junior High School. The study was conducted in descriptive quantitative research design. The data were taken from students' work composing Islamic Mathematics complex Questions. Auxiliary verb which are investigated on this study are 'am, is, are, was, were, have, has, and had'. The result of the study proves that most students were not capable in applying auxiliary verbs in their writing, forget which the appropriate auxiliary and still need to improve their ability to divine the appropriate auxiliary verbs. Furthermore, it proves that they are able to create Mathematical complex with Islamic Integration.
\end{abstract}

Keywords: Islamic Mathematical complex, Mathematics Department Students 
All of students in STKIP Al Hikmah must be able to teach Math using English. So, they must learn English from the first semester. They must improve their English before they graduate from STKIP Al Hikmah. For Mathematics students, writing in English become special things which need more effort. Writing skill is very important for them to transfer their ideas dealing with the courses. The writing is needed to share, show and describe their ideas. Students can improve their writing through some activities during their classes. The students will feel confident when they are able to create and write some emails, descriptions, profiles in social media, articles, and complex questions (Thompson, 2009).

They improve their writing in their daily activities and tries to write anything that they know even sometimes they make mistakes in choosing a correct auxiliary verb when they make some complex questions. The use of proper auxiliary verbs will help the students to create the complex questions. In some questions, auxiliary verbs become more important because the auxiliary verbs will impact to the which Mathematics rules used.

The most common auxiliaries are 'am, is, are, was, were, have, has, and had which are used for determining between countable and uncountable pronoun. Because they are not applying English in their daily life, sometimes they forget and careless about the correct auxiliary verbs for countable and uncountable pronoun. It is also because in their first language, Bahasa Indonesia, they don't need to make different verb between countable and uncountable pronoun, but in English they must make it different. Because in English, when they don't use the correct auxiliary verbs, it will change the whole meaning of that sentence. It is sometimes hard for them to divine the correct ending for the noun, even they have understood it, but sometimes they forgot to apply it.

In the third semester, they must take English for Writing class, and one of the projects of the course is writing Islamic Mathematical complex questions. Islamic Mathematics complex questions consist of story relate to Islamic value, because all students of STKIP Al Hikmah they are taught to be a da'i teacher with a good character.

Moreover, there are several previous study relate to this study, First, Özkan (2018) entitled Student Achievement in Turkey, According to Question Types Used in PISA 20032012 Mathematic Literacy Tests which dealing with how the type of question which more easily to be answered by students. Second, Sankar (2017) in his article entitled Pragmatic Comprehension of Different Types of Questions in Tamil which figure out that students will get different understanding about questions based on their basic knowledge. Based on the explanation above, the writer is going to analyze students' error in using auxiliary verbs in writing Islamic Mathematics complex questions. The gap of this study with the previous 
studies are both of the previous studies didn't ask student to create questions but they only answer the given questions, while in this study analyzed questions which they made by themselves. Furthermore, this study is conducted in the third semester of Mathematics Department students of STKIP Al Hikmah who takes English for Writing course. The writer focuses on students' work in composing some complex questions with Islamic integration since the objective of the course is to help the students in composing Islamic complex questions in English.

Based on the background of study, the research questions is what is the common error of auxiliary verbs in Islamic mathematical complex questions?. So, the purpose of this study was to investigate students' error in using auxiliaries in composing Islamic mathematical complex questions.

\section{THEORETICAL FRAMEWORK}

\section{Auxiliary Verbs}

In writing complex, it is important to considering about the grammar of the sentences, because it can divine the meaning of the sentences. Auxiliary verbs help main verbs in a sentence to differ whether it is a main clause or sub clause. It helps to express the aspect in the sentences. Auxiliary verbs also called helping verbs. Auxiliary do not make up a verb phrase on their own but help to make up a verb phrase in combination with a main verb. For instance, I am studying in my class is different with I study in my class, by adding the auxiliary verb we can conclude that the first sentence is still doing the study, while the second sentence we do not know whether it has been done or not.

There are two types of auxiliary verbs, primary auxiliary verbs (do, have, be) and modal auxiliary verbs (can, could, may, might, shall should, will would, must, used to, ought to, dare, need). Primary auxiliaries also act as main verbs.

For instance:

- $d o=$ form the do-construction

- have $=$ form the perfect aspect.

- $\quad b e=$ form the progressive aspect and form the passive.

Furthermore, in this research, the researcher only focus on several auxiliary verbs, those are 'am, is, are, was, were, have, has, and had'. Based on Hayat (2015), the use of auxiliary verbs is described in the table below: 
Similar with do, have is both a main verb and an auxiliary. It has the following forms.

\begin{tabular}{cllll}
\hline \multirow{2}{*}{ Base } & \multicolumn{2}{c}{ Positive } & \multicolumn{2}{c}{ Negative } \\
\cline { 2 - 5 } & have & 've & have not, 've not & haven't \\
\hline -s form & has & 's & hasn't, 's not & hasn't \\
\hline past & had & 'd & had not, 'd not & hadn't \\
\hline -ing form & having & & not having & \\
\hline -ed participle & had (only as lexical verb) & & & \\
\hline
\end{tabular}

Behas eight different forms (which is more than any other English verb). Be is constructed as an auxiliary also when it functions as a main verb. For example, it has no doconstruction (except in commands)

\begin{tabular}{|c|c|c|c|}
\hline Base & Positive & & \\
\hline Present $1^{\text {st }}$ person singular & $\mathrm{am}, ' \mathrm{~m}$ & am not, 'm not & $($ aren't, ain't) (a) \\
\hline $3^{\text {rd }}$ person singular & is, 's & is not, 's not & isn't \\
\hline $2^{\text {nd }}$ person singular & are, 're & had are not, 're not & aren't \\
\hline and all person plural & & & \\
\hline Past $1^{\text {st }}$ person singular & was & was not & wasn't \\
\hline $2^{\text {nd }}$ person singular and & & & \\
\hline $1^{\text {st }}$ and $3^{\text {rd }}$ person plural & were & were not & weren't \\
\hline -ing form & being & not being & \\
\hline -ed participle & been & & \\
\hline
\end{tabular}

(Hayat, 2015)

\section{Islamic Complex Questions}

In Mathematics, it is common to have questions in complex, the questions are dealing with a story of someone or something and the students need to count the things in the story. One of the examples of complex question is 'My mother has twenty oranges and she wants to give charity to ten orphans, so how many oranges for one orphan?'. It is one of example of Islamic complex Question.

In English for Writing course, they must create minimum 50 questions for each student, and they must choose a topic based on Mathematics topic in VIII grade of Junior High School. Because they will teach in Indonesia, which is English as ESL (English as a Second Language), the English Mathematics is a program specifically designed to teach 
Mathematics in English for speakers who are using English as their second language. The goal for learners is to achieve better proficiency in academic and social language. ESL is also called English Language Development (ELD),(Einhorn, 2001).

Islamic value is given in each of the questions they made, so besides transfer knowledge about Mathematics, they also transfer and share the social culture of Islamic environment. The students also may develop and modify some Islamic story from the Sahabah of Rosululloh.

\section{RESEARCH METHODOLOGY}

This study used descriptive quantitative research design. The participants of this research were nine Math students of STKIP Al Hikmah who took English for Writing course on the third semester. The data of the study was students' work in composing in Islamic complex Math Questions. The data were then examined and analyzed carefully to get the accurate result of this study.

Since our study is concerned with error in writing, this study used descriptive quantitative research design. The participants for this study were 9 students from Mathematics Department at STKIP Al Hikmah Surabaya. In this study, firstly the subjects are being asked to create a project. The project is writing 50 questions complex in English with eight grade topics. After 4 weeks, the researcher will ask the students to present in front of the class and all the member of the class will give some suggestions and comments regarding to the questions which they have made. Moreover, after they present, they will revise and submit the revision. The data of the research is their revision of Islamic complex. There will two revisions first and second revision. The researcher will count how many mistakes of auxiliary verbs in the first revision and how many mistakes in the second revision.

\section{Instruments}

Two research instruments were used to collect data for this research, namely the first revision and second revision Islamic question complex. Since this study was small scale, using the two instruments for data collection would help to validate the findings; the findings from all the instruments could converge to present the result of this research. Data gathered from the first and second revision were counted and tabulated to make comparison of students' achievement. Later analyses were done accordingly. 


\section{Data analysis:}

After collecting data, the researcher started to analyse the data. The data analyses of this study will do based on the frequency counting method and the findings will recorded in two phases. The first one was done as soon as the first revision was over. The scores will record and tabulated for easy reference of comparison later. The second phase was done right after the second revision took place. Again, the scores were recorded and tabulated for comparison too.

Most importantly, after the second revision, the improvement will calculate and converted into percentage to be used in the discussion of findings later. All these numbers were presented in the forms of tables so that the reader could have easy comprehension of the first revision result, the second revision result and the improvement of the students.

\section{FINDINGS AND DISCUSSIONS}

The purpose of this study was to investigate students' error in using auxiliaries in composing Islamic mathematical complex questions. The students on this study were given several tasks about how to make Islamic complex Math question and their error in using auxiliaries mark in their work.

Table 1. An Example of Analysis Result

\begin{tabular}{|c|c|c|}
\hline No & Students' work & Kinds of errors \\
\hline 1. & $\begin{array}{l}\text { Galih and Ipang are mahasantri in } M a \text { 'had Aly Surabaya. They } \\
\text { memorized al-Quran in the } M a \text { 'had. Sunday is the time for } \\
\text { intensive tahfidz, Galih can memorize } 3 \text { pages within } 1 \text { hour } \\
\text { while Ipang can memorize } 4 \text { pages. If the total time Galih and } \\
\text { Ipang memorize is } 16 \text { hours and their targets is } 55 \text { pages then } \\
\text { how many hours Galih complete } 55 \text { pages? }\end{array}$ & $\begin{array}{l}\text { Misplacing 'is' } \\
\text { should be 'are' }\end{array}$ \\
\hline 2 & $\begin{array}{l}\text { Fairus reading Sirah Nabawiyah in the books explain about } \\
\text { history prophet Muhmmad SAW. Muhammad SAW it is a one } \\
\text { of messenger have titled Ulul Azmi. Now, he knows about } \\
\text { prophet and messenger that have titled Ulul Azmi. The set } \\
\text { prophet and messenger that have titled Ulul Azmi. We get B = } \\
\text { \{the set prophet and messenger that have titled Ulul Azmi\}. So. } \\
\mathrm{n}(\mathrm{B}) \text { is.... }\end{array}$ & $\begin{array}{l}\text { Misplacing 'have' } \\
\text { should be 'has' }\end{array}$ \\
\hline
\end{tabular}




\begin{tabular}{|c|c|c|}
\hline No & Students' work & Kinds of errors \\
\hline 3. & $\begin{array}{l}\text { Q.S Al Mujadalah ayah } 11 \text { that Allah SWT will raise level beliefs } \\
\text { and bookish (have knowledge). Because that Galih with his old } \\
\text { friends going to visit Gramedia book store for buys several } \\
\text { books. Then, Galih bought book with tittle "MUJAHID". After } \\
\text { that, he come back to Galih's home. Divine in the curly braces } \\
\text { of set, the set of alphabet from tittle of Syahid's book? }\end{array}$ & $\begin{array}{l}\text { Misplacing 'have' } \\
\text { should be 'has' }\end{array}$ \\
\hline 4 & $\begin{array}{l}\text { Ipang are always reciting sentence: tahmid, tasbih and takbir as } \\
\text { many } 30 \text { times after prays. From the expression get } \mathrm{P}=\{\text { set of } \\
\text { sentence that always read by Ipang after prays }\} \text { or we can written } \\
\text { as } \mathrm{P}=\{\text { tabmid, tasbih, takbir\}. So, how many subsets } P \text { ? }\end{array}$ & $\begin{array}{l}\text { Misplacing 'are' } \\
\text { should be 'is' }\end{array}$ \\
\hline 5 & $\begin{array}{l}\text { Roy and Bangun was absent since two days ago because they is } \\
\text { sick. Rohim as his friend feels worry about it, they remember a } \\
\text { story about the Prophet Muhammad Peace be upon him that he } \\
\text { always visited his companions when his companions got sick. } \\
\text { Rohim is suggesting several friend to visit Roy's home to give } \\
\text { spirit. They bring guava juice in a cube bottle. If the length of } \\
\text { bottle is } 300 \mathrm{~cm} \text {, they bring ... litre of juice. }\end{array}$ & $\begin{array}{l}\text { Misplacing 'was' } \\
\text { should be 'were' }\end{array}$ \\
\hline 6 & $\begin{array}{l}\text { Himaptika hold mathematics exhibition which show learning } \\
\text { media by student of Mathematics department. There is many } \\
\text { kinds of shapes media, they is a cube frame, monopoly syari'ah, } \\
\text { and } 2 \mathrm{D} \text { shapes. The monopoly syari'ah is the game media for } \\
\text { children. It is about Islamic landmark, if the monopoly syari'ah } \\
\text { has length } 30 \mathrm{~cm} \text { and width } 30 \mathrm{~cm} \text {. So, the monopoly's area is } \\
\ldots . .\end{array}$ & $\begin{array}{l}\text { Misplacing 'is' } \\
\text { should be 'are' }\end{array}$ \\
\hline 7 & $\begin{array}{l}\text { The tickets was sold out and the committees also get } 500 \text { million } \\
\text { rupiahs from the auction. So, how much rupiah they get? }\end{array}$ & $\begin{array}{l}\text { Misplacing 'was' } \\
\text { should be 'were' }\end{array}$ \\
\hline 8 & $\begin{array}{l}\text { Sarah borrowed an Arabic dictionary in her school's library } \\
\text { because she got a homework from her Ustadzah. Yesterday is the } \\
\text { deadline to return the book but until today she doesn't return it. } \\
\text { So, she will buy the same book as her responsible. The book has } \\
1 \mathrm{~mm} \text { per sheet, if the thickness of the book is } 100 \mathrm{~cm} \text { without } \\
\text { cover. So, the book has... sheets. }\end{array}$ & $\begin{array}{l}\text { Misplacing 'is' } \\
\text { should be 'was' }\end{array}$ \\
\hline
\end{tabular}


$9 \quad$ Syahid and Rahmad has to join Indonesian Red Crescent last

Misplacing 'has'

week. They will go to Yogyakarta tomorrow for helping people

should be 'have'

there. They bring stretcher and a tent. If the stretcher's weight is

$5 \mathrm{~kg}$. so, the total heavy of 10 stretchers is ....

The table above showed several results of students' error in using auxiliaries. To get students' error frequency, the writer used the following formula.

$\mathrm{P}=\frac{F}{N} \boldsymbol{x} \mathbf{1 0 0} \%$

$\mathrm{P}=$ Percentage (kind of errors)

$\mathrm{F}=$ Frequency (number of error)

$\mathrm{N}=$ Total number of errors

The following is the qualification result of students' error in using auxiliaries.

Table 2. Students' error in using auxiliaries

\begin{tabular}{clcc}
\hline No & Kind of error & Total of error & $\begin{array}{c}\text { Percentage of } \\
\text { error }\end{array}$ \\
\hline 1 & Using of 'am' & 0 & 0 \\
\hline 2 & Using of 'is' & 27 & 17 \\
\hline 3 & Using of 'are' & 19 & 12 \\
\hline 4 & Using of 'was' & 22 & 14 \\
\hline 5 & Using of 'were' & 16 & 10 \\
\hline 6 & Using of 'have' & 31 & 20 \\
\hline 7 & Using of 'has' & 43 & 27 \\
\hline & Total & 158 & $100 \%$ \\
\hline
\end{tabular}

The purpose of table above is to describe student's error in using auxiliaries in writing Islamic complex question. There result showed that there were 158 auxiliaries' errors that students make in their writing. Most students were not able to use proper 'has' form in their writing. The number of errors in applying 'has' according to the data were $43(27 \%)$. The analysis of students' work in applying 'has' showed that there were two factors that influence this obstacle. The first, most students forget without when they need to use 'have' and when they need to use 'has'. Many students did not use 'has' when they 
made a sentence which had single pronoun. The following were some students' mistake in using 'has' for plural pronoun.

Table 3 The sum findings of auxiliaries use

\begin{tabular}{clcc}
\hline No & Kind of error & Total of findings & $\begin{array}{c}\text { Percentage of } \\
\text { findings }\end{array}$ \\
\hline 1 & Using of 'am' & 20 & 2 \\
\hline 2 & Using of 'is' & 58 & 6 \\
\hline 3 & Using of 'are' & 257 & 25 \\
\hline 4 & Using of 'was' & 105 & 10 \\
\hline 5 & Using of 'were' & 162 & 16 \\
\hline 6 & Using of 'have' & 185 & 18 \\
\hline 7 & Using of 'has' & 231 & 23 \\
\hline & Total & 1018 & 100
\end{tabular}

The misplacing of 'has' in plural pronoun also occurs when the students use 'was' for plural pronoun. Even though they have understood how to apply 'has' and 'have', but when they make the complex questions, most of them forget about the rule.

The error of using 'has' also occurs when the students make a sentence which the meaning is 'must'. Many students apply 'have' instead of 'has' for singular pronoun. The following was the example of students' error: Syahid has to join Indonesian Red Crescent last week. They will go to Yogyakarta tomorrow for helping people there. They bring stretcher and a tent. If the stretcher's weight is $5 \mathrm{~kg}$. so, the total heavy of 10 stretchers is.......

The result of the analysis of students' work also showed that there were $14 \%$ error that the students made in the use of 'was' for singular pronoun. Most students did not use 'was' for singular pronoun in the sentence. The following were students' error in using 'was' in a sentence. Sarah borrowed an Arabic dictionary in her school's library because she got a homework from her Ustadzah. Yesterday was the deadline to return the book but until today she doesn't return it. So, she will buy the same book as her responsible. The book has 1 mm per sheet, if the thickness of the book is $100 \mathrm{~cm}$ without cover. So, the book has ... sheets.

\section{CONCLUSION}

The result of the study showed that most of Mathematics students met difficulties in using proper auxiliaries in a sentence. The findings explained that most students made an error of using proper 'has' in a sentence. The students also made a mistake in using 
'was'. Most of them was not consistent in using 'was' for proper noun in a sentence. The findings also showed that the students made several mistakes in using 'is', 'are', 'were', and 'have'.

\section{REFERENCES}

Einhorn, K. (2001). ESL Activities and Mini-Books for Every Classroom. Retrieved from http://www.amazon.com/dp/0439153913/ref=wl_it_dp_o_pd_S_ttl?_encoding=U TF8\&colid=34VCEHGG5K3UL\&coliid=I1PWXDN9K3L4E3

Hayat, M. (2015). Importance of the Usage of Multiple Auxiliary Verbs in English Language in the Corpus Approach / Group Learning of the Students of Bachelor Level in District Kohat, 5(3), 221-228.

Thompson, T. (2009). Oxford Primary Skills 1. Reading and Writing.

Özkan, Y. Ö., \& Özaslan, N. (2018). Student Achievement in Turkey, According to Question Types Used in PISA 2003-2012 Mathematic Literacy Tests. International Journal of Evaluation and Research in Education, 7(1), 57-64. Retrieved from https://eresources.perpusnas.go.id:2057/login?url=https://search.ebscohost.com/login.aspx?d irect=true $\& \mathrm{db}=$ eric $\& A \mathrm{~N}=\mathrm{EJ} 1174883 \&$ site=eds-live

Sankar, A., Raghunathan, V., Boominathan, P., \& A., U. R. (2017). Pragmatic Comprehension of Different Types of Questions in Tamil. Language in India, 17(11), 1-17. Retrieved from https://eresources.perpusnas.go.id:2057/login?url=https://search.ebscohost.com/login.aspx?d irect $=$ true $\& \mathrm{db}=$ ufh $\& A N=126488932 \&$ site $=$ eds-live 